\title{
Sosialisasi Belajar Calistung Pada Anak Usia Dini Bersama Orang Tua Hebat
}

\author{
Denok Julianingsih*, Indri Dwi Isnaini \\ STKIP Bina Insan Mandiri, Surabaya, Indonesia \\ *Coresponding Author: denokjulianingsih@stkipbim.ac.id \\ Dikirim: 23-12-2021; Direvisi: 30-12-2021; Diterima: 02-01-2022
}

\begin{abstract}
Abstrak: Pengabdian ini bertujuan untuk memberikan pemahaman dan keterampilan kepada wali murid dari TK Dharmawanita Ngembeh tentang bagaimana mengajarkan calistung pada anak usia dini di rumah selama masa pandemi. Pengabdian ini dilaksanakan dengan melakukan kegiatan parenting berupa sosialisasi kepada wali murid dengan memberikan materi tentang mengajarkan CALISTUNG pada anak usia dini melalui permainan. Langkahlangkah dalam pengabdian ini terdiri dari tiga tahapan yaitu perencanaan, pelaksanaan, dan evaluasi kegiatan. Setelah dilakukannya kegiatan parenting ini, ada hasil yang positif seperti, puasnya mereka pada materi yang disampaikan oleh narasumber kemudian pemberian contoh konkrit terkait aplikasi dalam mengajarkan CALISTUNG di rumah melalui kegiatan bermain dan juga banyaknya antusias dari wali murid saat kegiatan berdiskusi.
\end{abstract}

Kata Kunci: calistung, anak usia dini, PAUD, sosialisasi, parenting

\begin{abstract}
This service aims to provide understanding and skills to the guardians of students from Dharma Wanita Ngembeh Kindergarten on how to teach calistung to early childhood children at home during the pandemic. This service is carried out by carrying out parenting activities in the form of socialization to parents by providing material about teaching CALISTUNG to early childhood through games. The steps in this service consist of three stages, namely planning, implementing, and evaluating activities. After this parenting activity was carried out, there were positive results such as, they were satisfied with the material presented by the resource persons then gave concrete examples related to applications in teaching CALISTUNG at home through playing activities and also a lot of enthusiasm from the parents during discussion activities.
\end{abstract}

Keywords: calistung, early childhood, PAUD, socialization, parenting

\section{PENDAHULUAN}

Munculnya fenomena di lapangan, bahwa banyak sekolah-sekolah SD baik swasta maupun negeri atau bahkan sekolah favorit yang memberlakukan calon siswanya menguasai calistung sebagai syarat diterimanya siswa pada sekolah tersebut, menjadikan banyak sekali orang tua siswa khususnya anak usia dini yang menjelang masuk ke tingkat sekolah dasar berlomba-lomba untuk memasukkan putra putrinya pada TK/RA yang mengajarkan CALISTUNG sejak dini. Nasir (2018) mengatakan bahwa penguasaan calistung dijadikan sebagai patokan bagi sekolah sekolah SD/MI favorit. Calon siswa yang dapat menguasai CALISTUNG dengan kemampuan membaca, menulis, dan berhitung dengan baik, berkesempatan untuk masuk pada sekolah SD/MI favorit. Hal inilah yang menjadikan beberapa sekolah TK/RA sudah memberlakukan calistung sejak dini pada kurikulum pembelajaran mereka.

Fenomena tersebut, menjadikan orang tua banyak yang beranggapan bahwa putra-putrinya sebelum masuk ke tingkat SD/MI harus memiliki kemampuan 
CALISTUNG yang baik. Banyak persepsi orang tua yang beranggapan bahwa seorang anak dikatakan pintar jika dia dapat membaca, menulis dan berhitung dengan lancar. Tidak jarang bahwa tujuan orang tua memasukkan putra-putrinya ke TK/RA agar mereka memiliki kemampuan calistung yang baik. Hal itu dikarenakan ada ketakutan dalam diri orang tua bahwa anaknya tidak akan diterima masuk SD/MI favorit jika tidak memiliki kemampuan CALISTUNG (Napitu \& Nasriah, 2019). Hal inilah yang menyebabkan pro dan kontra, karena pada dasarnya pembelajaran calistung tidak sesuai dengan prinsip pendidikan anak usia dini.

Berdasarkan UU Sisdiknas No. 20 tahun 2003 tentang sistem pendidikan nasional menyatakan bahwa Pendidikan Anak Usia Dini (PAUD) adalah suatu upaya pembinaan yang ditujukan kepada anak yang baru lahir sampai anak usia 6 tahun yang dilakukan melalui pemberian rangsangan pendidikan untuk membantu pertumbuhan dan perkembangan jasmani dan rohani anak agar memiliki kesiapan untuk menghadapi jenjang pendidikan serta tahapan kehidupan berikutnya. Dimana bentuk penyelenggaran pendidikan di PAUD menitikberatkan pada pertumbuhan dan perkembangan fisik anak yaitu koordinasi antara motorik halus dan motorik kasar, kecerdasan, bahasa dan komunikasi pada tahap-tahap perkembangan yang dilalui anak usia dini. Berkaca pada hal tersebut pendidikan di TK/RA pada anak usia dini seyogyanya diberikan sebuah kegiatan yang dapat merangsang motorik halus maupun kasarnya seperti kegiatan bermain dengan menggunakan alat permainan edukatif. Hal ini sejalan dengan yang dikatakan Nasir (2018) yang menyatakan bahwa kegiatan yang dilakukan di taman kanak-kanak hanyalah bermain dengan menggunakan alat-alat bermain edukatif. Kegiatan seperti membaca, menulis, dan berhitung tidak diperkenankan kecuali hanya mengenalkan huruf-huruf dan angka-angka.

Bermain menjadi sebuah sarana yang penting bagi perkembangan anak usia dini. Napitu \& Nasriah (2019) menganggap bahwa pendidikan anak usia dini merupakan pendidikan melalui pemberian kesempatan bagi anak untuk dapat menikmati dunianya. Salah satu caranya adalah dengan bermain. Karena pada dasarnya menciptakan pembelajaran pada anak usia dini tidaklah sama dengan anak usia di atasnya. Dimana tahap perkembangan pada anak usia dini berada pada tahapan golden age yaitu segala aspek perkembangan anak sedang berkembang sehingga dibutuhkan sebuah sarana/ fasilitas yang mampu merangsang tahapan perkembangan tersebut.

Faktanya, di lapangan banyak sekali orang tua yang mengajarkan anaknya untuk belajar membaca, menulis, dan berhitung dengan cara memaksa. Bahkan, selama proses pembelajaran di masa pandemi ini, beberapa sekolah TK/RA masih menerapkan pembelajaran secara daring, sedangkan beberapa sekolah yang lain melakukan pembelajaran secara blanded learning yaitu membagi siswa secara dua kelompok yaitu ada yang sebagian belajar dari rumah dan ada yang sebagian belajar di sekolah secara tatap muka. Hal ini menyebabkan, orang tua secara tidak langsung menghadapi putra-putrinya untuk belajar dari rumah. Kejadian ini menjadikan orang tua berinteraksi secara langsung dalam mengajarkan putra-putrinya untuk menguasai calistung. Berdasarkan hasil dari wawancara beberapa wali murid di TK Dharmawanita Ngembeh, kebanyakan dari mereka yang frustasi karena saat anaknya diajarkan membaca, menulis maupun berhitung banyak yang tidak bisa, menangis, bosan, atau bahkan tidak mau untuk belajar.

Kebosanan siswa saat belajar CALISTUNG dikarenakan ada pemaksaan belajar dari orang tua, penciptaan suasana belajar yang salah atau bahkan metode yang kurang 
tepat. Orang tua seringkali lupa bahwa, usia 4-6 tahun adalah masa-masa dimana perkembangan anak usia dini akan maksimal jika dilakukan melalui sebuah permainan menarik yang dapat menjadikan pembelajaran tersebut lebih menyenangkan. Lisnawati (2020) mengatakan bahwa prinsip pendidikan anak usia dini adalah belajar melalui bermain dengan menggunakan media yang menarik perhatian anak. Untuk itu perlu adanya pemahaman baru bagi orang tua dalam mengajarkan calistung pada putra-putrinya di rumah.

Salah satu upaya yang dapat dilakukan untuk merubah pemahaman orang tua dalam mendampingi putra-putrinya saat belajar di rumah adalah dengan memberikan kegiatan parenting yaitu sosialisasi tentang bagaimana mengajarkan CALISTUNG yang tepat bagi anak usia dini. Kegiatan parenting sendiri sangatlah perlu untuk dilakukan karena kegiatan ini merupakan wadah untuk saling bertukar pikiran serta berkomunikasi antara orang tua dengan orang tua dan juga orang tua dengan pendidik. Dalam kegiatan tersebut orang tua akan diberikan pemahaman tentang bagaimana mengajarkan membaca, menulis, dan berhitung yang tepat sesuai tahap perkembangan anak usia dini yaitu mengemas pembelajaran dengan cara bermain. Melalui bermain kreatif, seorang anak dapat mengintegrasikan semua kemampuannya, dan juga dapat membangun pengetahuannya sendiri dengan melakukan percobaan melalui obyekobyek nyata di sekitarnya (Marlisa, 2016)

Moeslichatoen dalam (Marlisa, 2016) menyatakan bahwa bagi seorang anak, bermain dapat memberikan kepuasan tersendiri bagi mereka karena bermain merupakan kegiatan yang nonserius dan fleksibel. Dimana bermain pada anak lebih ditekankan kepada proses dari bermain itu sendiri dibandingkan pada hasil yang diperoleh dari kegiatan tersebut. Berdasarkan hal tersebut, dapat dikatakan bahwa pembelajaran pada anak usia dini adalah belajar sambil bermain dan bermain sambal belajar.

Berkaitan dengan hal di atas, kami mengadakan pengabdian dengan tema, "Belajar Calistung Untuk Anak Usia Dini Bersama Orang Tua Hebat". Tujuan dari kegiatan pengabdian ini adalah memberikan pemahaman kepada orang tua bahwa seorang anak yang berusia 4-6 tahun tidak wajib dalam menguasai kemampuan CALISTUNG seperti dapat membaca, menulis, dan berhitung dengan lancar layaknya seorang anak yang sudah duduk di bangku sekolah dasar. Tetapi, kita masih bisa memberikan pengetahuan dasar tentang membaca, menulis dan berhitung tanpa harus memaksa anak untuk menguasainya, yaitu dengan memperkenalkan anak CALISTUNG melalui kegiatan bermain.

\section{METODE PELAKSANAAN KEGIATAN}

Kegiatan pengabdian ini dilaksanakan pada hari Senin tanggal 06 Desember 2021 pukul 09.00 WIB sampai dengan 12.00 WIB yang bertempat di TK Dharmawanita Ngembeh Kecamatan Dlanggu Kabupaten Mojokerto. Penyelenggaraan pengabdian pada masyarakat ini merupakan kegiatan parenting dengan sasaran wali murid dari siswa TK A dan TK B Dharmawanita Ngembeh. Kegiatan parenting diberikan oleh dua orang narasumber yaitu Ibu Denok Julianingsih, M.Pd untuk materi berhitung dan Ibu Indri Dwi Isnaini, M.Pd. untuk materi membaca dan menulis. Pelaksanaan kegiatan parenting dihadiri sebanyak 25 orang wali murid baik dari TK A maupun TK B. 
Metode yang digunakan dalam pengabdian ini adalah deskriptif analisis. Sudjana dalam (Julianingsih, 2018) menjelaskan bahwa deskriptif analisis merupakan suatu metode untuk mendeskripsikan suatu gejala, peristiwa, kejadian yang terjadi saat ini serta memusatkan perhatian pada pemecahan masalah yang aktual sebagaimana adanya saat kegiatan dilaksanakan. Dalam rangka memecahkan masalah tersebut, tim pengabdian melakukan kegiatan parenting yang berfokus pada memberikan pengetahuan dan pemahaman kepada wali murid tentang bagaimana mengenalkan dan mengajarkan CALISTUNG pada anak usia dini dengan cara yang lebih menyenangkan seperti menggunakan metode permainan.

Pengabdian ini dilaksanakan dengan 3 tahapan yaitu perencanaan, pelaksanaan dan evaluasi. Adapun langkah-langkah pengabdian pada kegiatan parenting sosialisasi wali murid dengan tema, "Belajar Calistung untuk Anak Usia Dini Bersama Orang Tua Hebat" dapat dilihat pada diagram berikut ini:

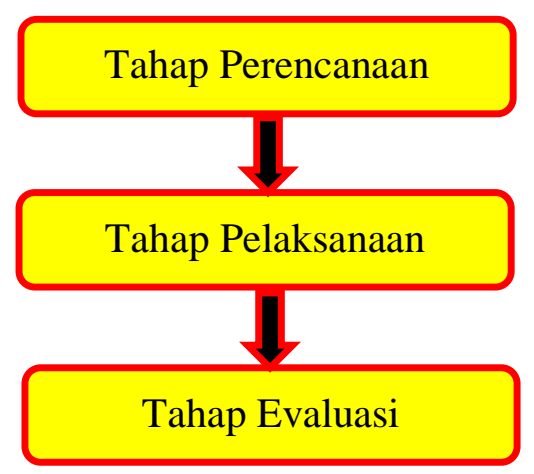

Diagram 1. Tahapan Pengabdian - Sosialisasi Kegiatan Parenting

Adapun secara rinci, detail langkah-langkah pengabdian sebagai berikut:

\section{Tahap Perencanaan}

Tahap perencanaan merupakan tahapan awal kegiatan. Pada tahap ini, tim pengabdian menghubungi sekolah mitra untuk menjalin kerjasama. Setelah dipastikan ada kerjasama, tim pengabdian bersama Kepala Sekolah dan Guru melakukan rapat intern untuk mengidentifikasi permasalahan yang ditemukan pada anak usia dini saat belajar dari rumah di masa pandemi. Selain itu, tim pengabdian juga menanyakan hal terkait kebutuhan para Guru di TK Dharmawanita Ngembeh. Tim Pengabdian menyusun jadwal pengabdian dan merancang materi yang akan disampaikan nantinya. Selain itu, tim pengabdian juga mempersiapkan segala bentuk administrasi seperti menyebar undangan, membuat daftar kehadiran, angket respon setelah penyampaian materi, menyiapkan LCD yang akan digunakan saat acara, kamera dan handycam untuk dokumentasi dan juga konsumsi yang akan dibagikan ke seluruh peserta.

\section{Tahap Pelaksanaan}

Pelaksanaan pengabdian pada kegiatan parenting berupa sosialisasi cara mengajarkan CALISTUNG pada anak usia dini bersama orang tua hebat menggunakan metode ceramah dan diskusi. Dua orang narasumber secara bergantian memberikan materi dengan waktu penyampaian untuk masing-masing narasumber kurang lebih 1 jam, termasuk diskusi dengan peserta didalamnya. Pada tahapan ini, selain narasumber memberikan materi, narasumber juga melakukan 
diskusi secara langsung pada peserta kegiatan, dimana peserta dapat mengajukan pertanyaan atau menceritakan kondisi yang dialami saat mengajarkan anak CALISTUNG di rumah. Narasumber dapat langsung menanggapi pertanyaan atau cerita yang disampaikan peserta, sedangkan peserta lain juga dapat ilmu baru baik dari materi yang disampaikan oleh narasumber ataupun pertanyaan yang dilontarkan oleh peserta.

\section{Tahap Evaluasi}

Tahap evaluasi merupakan bagian dari tahapan terakhir kegiatan pengabdian. Pada tahap ini, sebelum acara sosialisasi ditutup, tim pengabdian membagikan angket respon kegiatan sosialisasi kepada seluruh peserta untuk mengetahui tanggapan yang sejujurnya dari peserta kegiatan tentang materi yang sudah disampaikan oleh narasumber. Setelah tim pengabdian menerima seluruh angket respon, data angket respon tersebut akan diolah dan dianalisis untuk mengetahui kekurangan, maupun saran, kritik dan harapan peserta untuk kegiatan pengabdian selanjutnya.

\section{IMPLEMENTASI KEGIATAN DAN PEMBAHASAN}

Kegiatan pengabdian ini dilaksanakan di TK Dharmawanita Ngembeh Kecamatan Dlanggu Kabupaten Mojokerto pada hari Senin tanggal 06 Desember 2021 pukul 09.00 WIB - 12.00 WIB. Kegiatan ini dimulai dengan perencanaan yang disusun secara matang oleh tim pengabdian STKIP Bina Insan Mandiri. Mulai dari mendatangi sekolah mitra untuk diskusi dengan Kepala Sekolah dan Guru tentang kondisi, kebutuhan atau kesulitan yang dialami. Menyusun jadwal, menyiapkan materi dan kelengkapan-kelengkapan lainnya yang dibutuhkan selama kegiatan sosialisasi seperti peralatan LCD, kamera, handycam, dokumen administrasi, dan konsumsi peserta.

Dalam kegiatan tersebut, wali murid diberikan sosialisasi tentang bagaimana mengajarkan CALISTUNG bagi anak usia dini yang tepat tanpa harus memaksa anak untuk belajar. Tim pengabdian merasa materi ini sangat pas diberikan kepada wali murid, mengingat saat ini wali murid yang lebih dekat secara langsung dengan putraputrinya saat belajar dari rumah di masa pandemi. Berdasarkan hasil diskusi kecil yang disampaikan oleh Guru TK A dan TK B Dharmawanita Ngembeh, banyak sekali keluhan yang disampaikan oleh wali murid saat pembelajaran online di masa pandemi. Wali murid merasa kualahan, lebih sering marah-marah karena target membaca, menulis dan berhitung yang tidak sesuai ekspektasi atau bahkan anak yang tiba-tiba mogok saat belajar karena orang tua yang selalu memaksa dan beban tugas yang dirasa terlalu banyak oleh anak.

Pada dasarnya hal tersebut terjadi dikarenakan pemahaman masyarakat yang sudah salah kaprah. Kebanyakan wali murid menganggap bahwa anak usia dini yang masih duduk di TK/RA wajib bisa membaca, menulis, dan berhitung dengan lancar. Hal ini dikarenakan tuntutan saat masuk ke jenjang selanjutnya yaitu di tingkat SD/MI yang mengharuskan anak harus sudah bisa membaca, menulis dan berhitung (CALISTUNG) dengan lancar. Sering kali orang tua lupa, bahwa anak-anak di usia dini dunianya adalah bermain, sehingga jika anak terlalu diberikan beban yang lebih untuk belajar atau bahkan pemaksaan untuk menguasai CALISTUNG sejak dini, anak akan menjadi stres atau bahkan anak akan merasakan trauma sejak dini. Jika mengajarkan CALISTUNG dilakukan tanpa pendekatan yang menyenangkan, ditakutkan kreativitas anak juga akan terbatasi karena belajar yang dikemas dengan 
cara yang salah. Seharusnya, lingkungan belajar untuk anak usia dini diciptakan dengan cara belajar sambal bermain dan bermain sambil belajar.

Sejalan dengan yang disampaikan oleh Lisnawati (2020) bahwa prinsip pembelajaran pada anak usia dini adalah belajar dengan menggunakan permainan dengan media yang menarik. Hal ini akan sesuai dengan tahapan perkembangan anak usia dini. Mengajarkan calistung itu perlu, mengingat kebutuhan siswa saat masuk di jenjang selanjutnya dan kebutuhan di era globalisasi saat ini yang mana seorang siswa harus memiliki kemampuan dasar seperti membaca, menulis dan berhitung, tetapi kita perlu mengenalkan CALISTUNG dengan cara yang benar tanpa pemaksaan. Sufa \& Setiawan (2020) juga mengatakan bahwa kemampuan literasi yang dibutuhkan pada era globalisasi saat ini adalah memiliki kemampuan dasar seperti membaca, menulis, dan berhitung. Kemampuan CALISTUNG sangat dibutuhkan sebagai pijakan dasar dalam mengenalkan berbagai literasi pada anak usia dini. Kemampuan literasi ini baik dari segi bahasa ataupun kemampuan matematika yang dapat dikenalkan pada anak usia dini.

Berdasarkan hal tersebut, kami tim pengabdian STKIP Bina Insan Mandiri merasa perlu untuk memberikan pemahaman kepada wali murid tentang bagaimana mengenalkan atau mengajarkan CALISTUNG pada anak usia dini dengan cara yang menyenangkan, sesuai dengan tahap perkembangan anak usia dini yaitu dengan menggunakan metode permainan. Metode permainan dirasa cukup efektif karena sesuai dengan prinsip belajar anak usia dini yaitu belajar sambil bermain dan bermain sambil belajar. Orang tua akan diberikan pemahaman tentang bagaimana membuat sebuah permainan yang sederhana yang bisa dilakukan di rumah atau lingkungan tempat tinggal tanpa harus membutuhkan biaya yang banyak tetapi pemberian konsep matematika yang harus dipelajari untuk anak usia dini juga tepat dan juga melatih kemampuan bahasa anak-anak dengan cara memperkuat komunikasi antara ibu dan anak.

Kegiatan sosialisasi diawali dengan pendataan administrasi wali murid yang dimulai pukul 08.30 WIB. Wali murid yang mengikuti kegiatan sosialisasi berupa parenting ini kebanyakan berprofesi sebagai ibu rumah tangga, beberapa juga ada yang berprofesi sebagai Guru. Proses pendataan peserta sosialisasi selama 30 menit dengan jumlah peserta yang datang berjumlah 24 orang yang keseluruhannya dihadiri oleh ibu dari siswa yang bersekolah di TK Dharmawanita Ngembeh. Proses pendataan peserta sosialisasi kegiatan parenting dapat dilihat pada gambar 1 berikut:

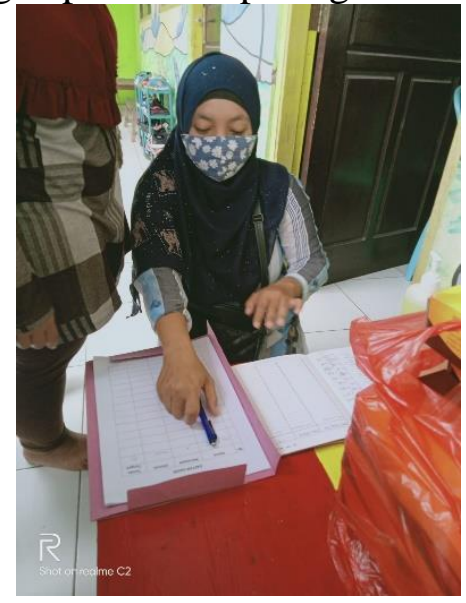

Gambar 1. Pendataan awal (absensi peserta) 
Pemberian materi sosialisasi dengan tema, "Belajar Calistung pada Anak Usia Dini Bersama Orang Tua Hebat" dimulai tepat pukul 09.00 WIB. Acara pertama dibuka dengan sambutan dari Ibu Dina Sari Agustin, S.Pd AUD selaku kepala sekolah TK Dharmawanita Ngembeh. Acara selanjutnya adalah penyampaian materi dari tim narasumber STKIP Bina Insan Mandiri. Materi pertama disampaikan oleh Ibu Indri Dwi Isnaini, M.Pd. berkaitan dengan materi membaca dan menulis. Sedangkan materi yang kedua disampaikan oleh Ibu Denok Julianingsih, M.Pd. berkaitan dengan materi berhitung.

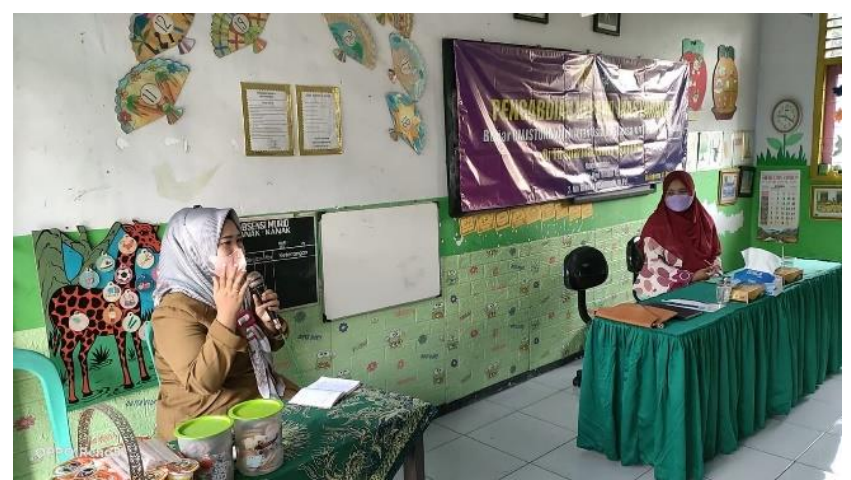

Gambar 2. Sambutan oleh Kepala Sekolah TK Dharmawanita Ngembeh

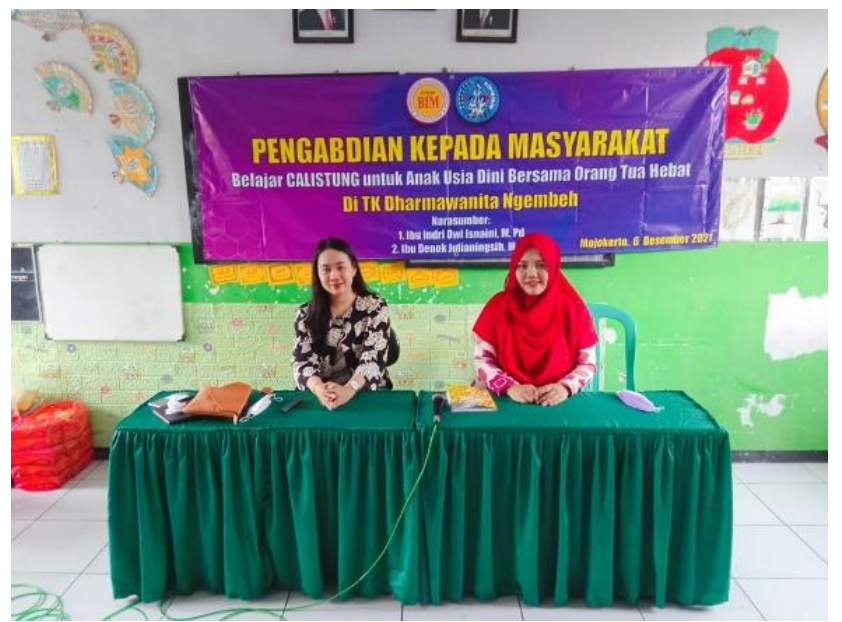

Gambar 3. Narasumber Ibu Denok Julianingsih, M.Pd. (kanan) dan Ibu Indri Dwi Isnani, M.Pd. (kiri)

Penyampaian materi pertama oleh Ibu Indri Dwi Isnaini, M.Pd berlangsung mulai pukul 09.20 - 10. 20 WIB. Pada materi yang disampaikan oleh narasumber pertama, narasumber menyampaikan tentang bagaimana melatih kemampuan Bahasa anak seperti membaca dan menulis. Narasumber juga menekankan pentingnya komunikasi dalam memperkuat bonding antara ibu dan anak. Pada awal materi, Ibu Indri Dwi Isnaini, M.Pd. menyampaikan tentang adanya fenomena yang berkembang pada masyarakat saat ini, yaitu anak usia dini di tingkat TK/RA berdasrkan kurikulum tidak boleh dipaksa baca atau tulis, tetapi saat akan masuk SD anak dituntut untuk harus sudah bisa baca atau tulis dengan lancar. Akibatnya, saat anak terlalu dipaksa belajar untuk harus bisa baca dan tulis, jam belajar anak tentunya akan malah bertambah dan jam bermain anak justru akan terpotong sehingga anak akan menjadi stress. 
Narasumber juga menekankan bahwa pengalaman belajar anak usia dini haruslah menyenangkan, dan disesuaikan dengan tahapan perkembangan anak usia dini. Pertiwi et al. (2021) juga mengatakan bahwa pengalaman belajar anak usia dini haruslah menyenangkan, tidak membebani anak. Mewajibkan anak untuk harus bisa membaca dan menulis dapat menjadikan anak stres dan akan menimbulkan trauma belajar tersendiri. Pada tahapan perkembangan belajar anak usia dini, haruslah belajar membaca dan menulis masih berupa pengenalan saja. Tahapan awal dapat mengenalkan huruf kepada anak dan lebih menekankan pada kegiatan bermain. Selain memperhatikan aspek kognitif anak, seyogyanya juga harus memperhatikan aspek yang lainnya seperti fisik motorik, bahasa, moral agama, sosial emosional dan seni. Komunikasi yang baik juga dapat melatih perkembangan aspek Bahasa anak. Seorang ibu yang jarang menjalin komunikasi dengan anaknya juga akan berpengaruh pada tahapan perkembangan bahasa anak. Pada dasarnya, bertanya tentang aktivitas/ kegiatan anak di sekolah, apa yang dia rasakan, apa yang dia alami, apa yang dia inginkan adalah menjadi bagian dari menjalin komunikasi untuk meningkatkan bonding antara ibu dan anak.

Pengenalan huruf-huruf dan pengenalan bunyi huruf kepada anak merupakan tahapan awal agar anak bisa membaca. Memperkenalkan dengan suara jelas bunyi dari setiap huruf agar anak dapat mengucapkan satu persatu huruf dengan jelas perlu untuk dilakukan dibandingkan dengan anak dipaksa untuk lancar membaca tanpa dikenalkan dulu. Hainstock dalam (Pertiwi et al., 2021) mengatakan bahwa membaca adalah pengenalan huruf-huruf ataupun bunyi huruf dengan metode memandang, memegang serta mencermati tiap huruf yang diucapkan satu persatu, setelah itu dicampur menjadi satu untuk membentuk sebuah perkataan pendek.

Ibu Indri Dwi Isnaini, M.Pd. juga menyampaikan kepada seluruh peserta sosialisasi, seyogyanya sebagai orang tua kita tidak terlalu memaksakan kehendak kepada anak untuk sesuatu yang dapat merugikan anak itu sendiri. Karena hal ini tentunya juga akan berdampak pada kesehatan mental si anak. Selain kesehatan mental anak akan terganggu yaitu anak menjadi stres, hal ini juga akan memicu anak untuk menjadi seorang pemberontak. Dewi \& Hasanah (2021) juga mengungkapkan bahwa pembelajaran CALISTUNG yang terlalu dipaksakan dan terkesan terburu-buru akan mempengaruhi kecerdasan mental anak seperti pikiran, emosi, sikap dan perasaan yang tercermin dalam sikap maupun perbuatan. Dimana kecerdasan mental tersebut salah satunya anak bisa menjadi pemberontak.

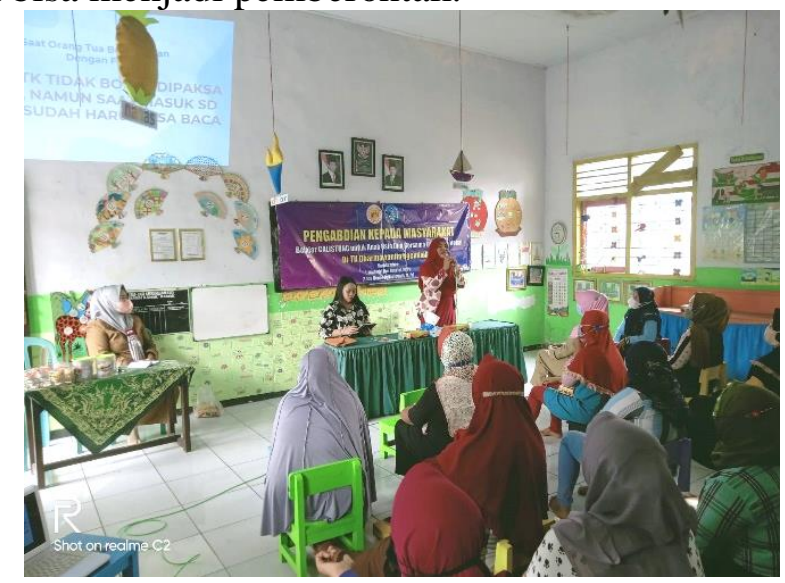

Gambar 4. Penyampaian materi oleh Ibu Indri Dwi Isnaini, M.Pd. 
Penyampaian materi kedua oleh Ibu Denok Julianingsih, M.Pd berlangsung mulai pukul 10.30 - 11.30 WIB. Pada materi yang disampaikan oleh narasumber kedua, narasumber menyampaikan tentang bagaimana mengenalkan konsep matematika yang tepat sesuai dengan perkembangan anak usia dini dengan menggunakan permasalahan kontekstual yang dikaitkan dengan kehidupan sehari-hari siswa, yang diaplikasikan dengan menggunakan permainan. Pada penyampaian awal Ibu Denok Julianingsih, M.Pd. melakukan Tanya jawab dengan peserta sosialisasi. Narasumber menanyakan bagaimana kondisi anak saat mereka belajar online selama masa pandemi. Sebagian besar orang tua mengatakan bahwa selama anak-anak belajar di rumah pada masa pandemi, mereka mengalami tingkat stress yang luar biasa, bahkan mereka mengatakan orang tuanya pun juga cukup stres saat mengajarkan anakanak materi berhitung. Setelah diskusi singkat dengan peserta sosialisasi, narasumber menyampaikan prinsip pembelajaran matematika pada anak usia dini yaitu 4-6 tahun. Prinsip tersebut adalah 1) mengenalkan pada situasi dunia nyata 2) menunjukkan bentuk konkrit/ gambar 3) mengaitkannya pada dunia matematika yaitu simbol-simbol matematika.

Prinsip pembelajaran matematika pada anak usia dini seharusnya menggunakan permasalahan kontekstual yaitu dengan mengaitkannya pada situasi dunia nyata. Setelah kita memberikan sebuah permasalahan yang dikaitkan dengan situasi dunia nyata. Hal ini dimaksudkan agar anak tidak asing pada cerita yang memang mereka alami pada kehidupan sehari-hari mereka. Prinsip selanjutnya yaitu permasalahan matematika dapat ditunjukkan dengan menggunakan bentuk konkritnya atau mungkin dalam bentuk sebuah gambar. Hal ini dimaksudkan karena pada tahap perkembangan anak usia dini, masih pada tahap berpikir konkrit belum ke tahapan berpikir abstrak. Sedangkan prinsip pembelajaran matematika yang terakhir adalah dapat memperkenalkan dengan dunia matematika sendiri yaitu simbol-simbol matematika. Jika anak-anak sudah mampu melakukan pembelajaran dengan menggunakan permasalahan kontekstual sampai kepada tahapan terakhir yaitu mengaitkan dengan simbol-simbol matematika maka prinsip pembelajaran bisa dibalik (Wahyuningsih et al., 2016).

Melibatkan anak pada permasalahan yang dekat dengan situasi dunia nyata menjadi penting karena ini akan menjadikan pengalaman belajar anak menjadi lebih bermakna. Selain itu, orang tua dapat memanfaatkan media atau sumber belajar lainnya agar pemahaman siswa dalam memvisualisasikan permasalahan kontekstual yang diceritakan dapat lebih konkrit bukan lagi abstrak yaitu hanya dengan bercerita saja tetapi tidak menunjukkan pada situasi nyatanya. Hal ini sesuai dengan apa yang disampaikan oleh Khadijah (2016) bahwa prinsip mengajarkan berhitung pada anak usia dini dapat diberikan secara bertahap yaitu diawali dengan menghitung bendabenda atau pengalaman konkrit yang dialami melalui pengamatan terhadap alam sekitar dan dengan melihat tingkat kesukarannya misalnya konkrit ke abstrak, mudah kesukar, dan dari sedehana ke yang lebih kompleks.

Selanjutnya, narasumber menyampaikan tentang tahapan-tahapan berhitung untuk dikenalkan pada anak usia dini diantaranya mengelompokkan, mengurutkan, membandingkan, mencocokkan, menghubungkan dan terakhir mengenalkan tipe-tipe pola. Pada tahapan-tahapan berhitung yang dapat dikenalkan pada anak usia dini, narasumber memberikan sebuah ilustrasi sederhana kepada peserta sosialisasi yang dapat dipraktekkan saat mengajarkan putra-putrinya di rumah. Sebagai contoh untuk 
mengenalkan konsep mengelompokkan, narasumber memberikan contoh mengelompokkan mobil yang terdapat pada sebuah parkiran mall, mengelompokkan sepeda motor yang terdapat pada sebuah parkiran mini market, mengelompokkan benda-benda di sekitar yang bentuknya menyerupai bangun datar ataupun bangun ruang, mengelompokkan jenis buah-buahan. Contoh-contoh tersebut dikemas dalam sebuah permainan dan disampaikan dalam sebuah cerita yang menyenangkan. Sebagai contoh, narasumber memberikan sebuah ilustrasi cerita, "Adik, kita tadi kan barusan dari pasar. Tadi di pasar kita sudah banyak membeli bahan-bahan makanan. Coba adik sebutkan tadi kita sudah membeli apa saja?". Setelah si anak menjawab pertanyaan si ibu, Ibu melanjutkan bertanya, "Nah ... tadi semua yang sudah kita beli, sudah kita masukkan di dalam satu kantong kresek ini. Coba sekarang adik bongkar isinya dan adik kelompokkan yang termasuk buah-buahan dan yang termasuk bumbu dapur".

Berdasarkan ilustrasi di atas dapat dilihat bahwa pengenalan matematika pada konsep pengelompokkan dikenalkan dengan cara yang menyenangkan. Matematika dihadirkan pada situasi dunia nyata dan dengan melibatkan anak secara langsung dalam mengkonstruk pengalamannya sendiri tentang pengelompokkan. Prinsip belajar sambal bermain ini lah, yang menjadikan pembelajaran anak menjadi lebih menyenangkan dan tentunya lebih bermakna. Hal ini sesuai dengan apa yang disampaikan oleh Utoyo \& Arifin (2017) bahwa permainan sangat penting dalam kegiatan perkembangan anak usia dini. Dengan permainan, stimulasi yang dilakukan akan dapat lebih mudah diterima oleh anak dan juga dapat meningkatkan kemampuan matematika awal pada anak usia dini.

Pengenalan konsep yang kedua yaitu konsep mengurutkan. Narasumber memberikan contoh aplikasi pengurutan dalam kehidupan sehari-hari yaitu mengurutkan buah nanas mulai dari kecil ke besar atau besar ke kecil, mengurutkan botol minuman berdasarkan tingginya, atau mengurutkan gelas yang berisi air berdasarkan banyak volume yang terdapat pada gelas. Narasumber menyampaikan bahwa semua contoh tersebut ada dekat dalam kehidupan sehari-hari anak. Orang tua tidak perlu mengeluarkan biaya yang cukup mahal untuk membeli alat peraga, cukup dengan menggunakan media yang terdapat di dalam rumah. Tentu saja contoh dari media yang sederhana ini, disampaikan dalam sebuah cerita yang menarik dan dikemas dalam sebuah permainan agar anak lebih termotivasi untuk belajar. Sebuah contoh yang dilustrasikan oleh narasumber agar belajar matematika lebih menyenangkan yaitu dengan permainan misalnya seluruh anggota keluarga atau mungkin teman sebaya yang terdapat pada lingkungan tempat tinggal, dapat diajak bermain bersama untuk mengurutkan botol minuman berdasarkan tingginya dengan cara balapan. Anak yang berhasil dapat diberikan reward berupa bintang, ucapan positif atau bahkan hadiah kecil. Hal ini dimaksudkan agar anak merasa usahanya dihargai dan mendapatkan pengakuan atas usahanya dan mendapatkan suasana belajar yang lebih menyenangkan.

Prinsip belajar dengan memperhatikan tahapan perkembangan pada anak usia dini yaitu bermain akan menjadikan anak belajar menjadi lebih menyenangkan dan membangkitkan semangat serta minat anak untuk terus belajar. Pratiwi (2015) mengatakan bahwa pembelajaran yang diterapkan dengan bermain adalah pembelajaran yang berpusat pada anak. Sehingga pada pembelajaran ini, anak akan dapat menerima pembelajaran tersebut tanpa adanya paksaan dari pendidik ataupun orang tua. Selain itu, anak-anak justru akan menganggap bahwa kegiatan belajar 
mereka tidak berubah dari kegiatan bermain, bahkan akan menganggap bahwa kegiatan belajarnya adalah kegiatan bermain.

Selanjutnya, narasumber menyampaikan tentang tahapan pengenalan matematika selanjutnya yaitu membandingkan, mencocokkan, menghubungkan, dan mengenalkan tipe-tipe pola. Setiap konsep matematika tersebut disampaikan dengan ilustrasi contoh sederhana yang dekat dengan kehidupan sehari-hari siswa dengan media atau sumber belajar yang dapat ditemukan di dalam rumah atau bahkan lingkungan sekitar tempat tinggal. Tidak hanya memberikan beberapa contoh kontekstual, narasumber juga memberikan contoh ataupun ilustrasinya dalam sebuah aturan permainan yang dapat dipraktekkan orang tua untuk putra-putrinya di rumah.

Sebagai penutup, narasumber menyampaikan kepada seluruh peserta sosialisasi bahwa pada dasarnya anak usia dini tidak harus dituntut untuk dapat menguasai calistung dengan baik. Anak usia dini cukup dikenalkan CALISTUNG dengan cara yang menyenangkan. Jika anak sudah kenal dengan CALISTUNG, mengenalkan dengan cara yang benar melalui permasalahan kontekstual dengan hal yang dikaitkan pada situasi dunia nyata dan mengemasnya dalam kegiatan bermain, anak-anak akan merasa bahwa kehidupan belajarnya tidak jauh berbeda dengan situasi yang sudah dia alami selama ini yaitu permainan. Sehingga, jika anak sudah merasa nyaman dan menyukai CALISTUNG maka selanjutnya mengajarkan calistung di tahapan selanjutnya yang lebih kompleks akan lebih mudah.

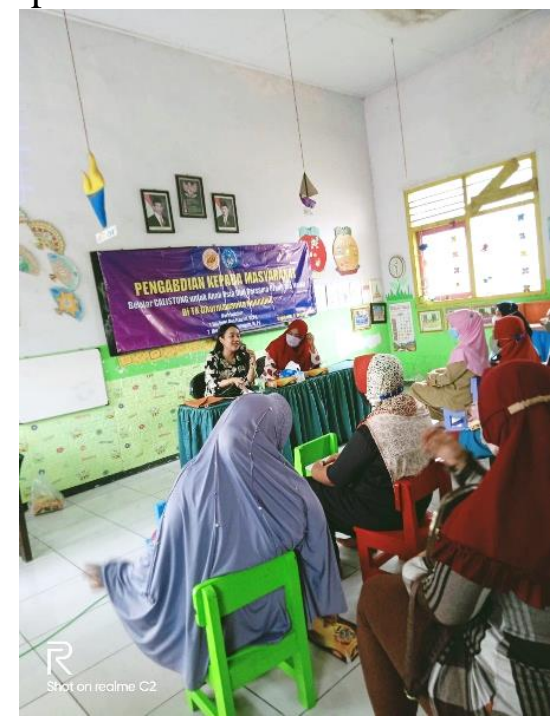

Gambar 5. Penyampaian materi oleh Ibu Denok Julianingsih, M.Pd.

Selanjutnya, di akhir kegiatan sosialisasi. Tim Pengabdian STKIP Bina Insan mandiri membagikan angket respon kepada seluruh peserta sosialisasi. Tim Pengabdian meminta wali murid, untuk mengisikan pengalamannya tentang apa yang dirasa, harapan, saran dan kritik terkait pelaksanaan kegiatan sosialisasi yang sudah dilaksanakan. Angket respon yang dibagikan terdiri dari 11 pertanyaan, diantaranya 9 pertanyaan dengan option jawaban antara rentang nilai 1- 4 dan 2 pertanyaan isian singkat. Pilihan option jawaban tersebut adalah 4 untuk kategori sangat baik/ sangat menarik/ sangat bermanfaat, 3 untuk kategori baik/ menarik/ bermanfaat, 2 untuk kategori tidak baik/ tidak menarik/ tidak bermanfaat dan 1 untuk kategori sangat tidak baik/ sangat tidak menarik/ sangat tidak bermanfaat. 


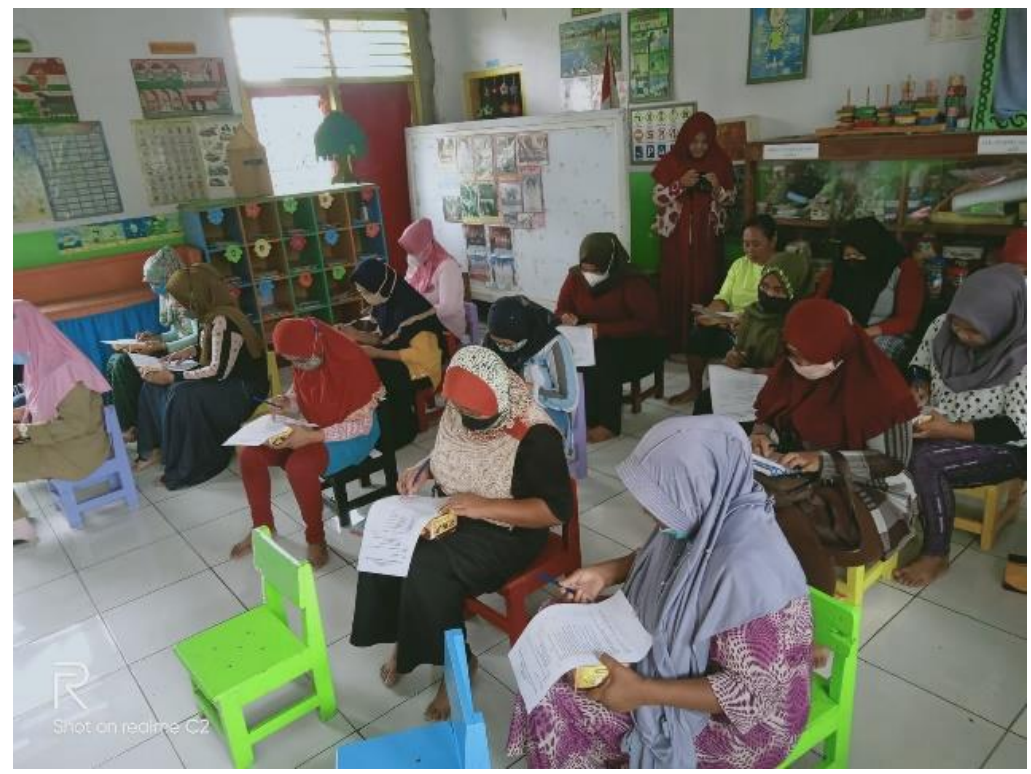

Gambar 6. Pengisian angket respon

Berdasarkan hasil analisis dari angket respon pelaksanaan kegiatan yang sudah diisi oleh 24 peserta sosialisasi didapatkan untuk indikator pertama, 15 orang peserta atau sekitar $62,5 \%$ peserta setuju bahwa waktu pelaksanaan parenting sangat baik dilakukan. Sedangkan sisanya sebanyak 9 orang peserta atau sekitar 37,5\% memberikan penilaian 3 atau pada kategori baik untuk waktu pelaksanaan parenting. Pada indikator kedua, sebanyak 21 peserta sosialisasi atau sekitar 87,5\% peserta memberikan penilaian 4 atau pada kategori sangat menarik untuk kesesuaian tema dengan materi yang disampaikan saat parenting. Sedangkan sisanya, sebanyak 3 orang peserta memberikan penilaian 3 atau pada kategori menarik.

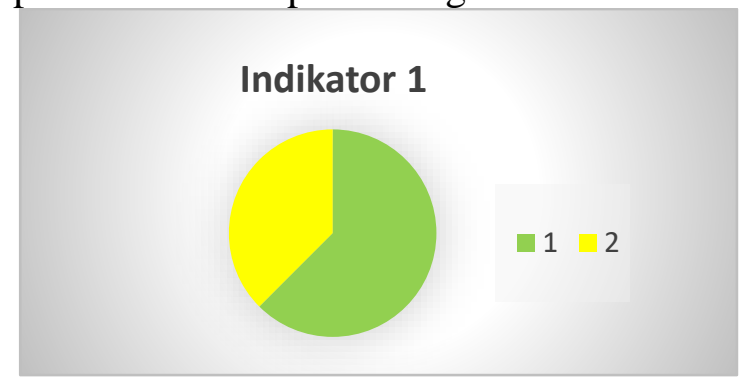

Gambar 6. Analisis Angket Respon Peserta pada Indikator 1

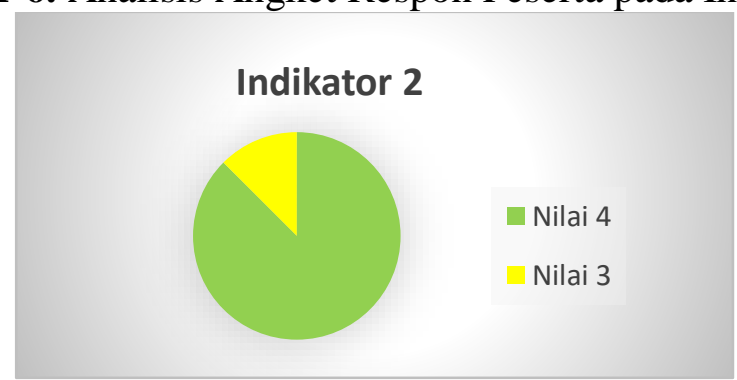

Gambar 7. Analisis Angket Respon Peserta pada Indikator 2

Indikator ketiga berkaitan dengan penyampaian materi yang disampaikan oleh narasumber Ibu Denok Julianingsih, M.Pd. yaitu sebanyak 18 orang peserta atau sebanyak $75 \%$ memberikan penilaian 4 yaitu pada kategori sangat menarik sedangkan 
sisanya sebanyak 6 orang peserta atau sebanyak $25 \%$ memberikan penilaian 3 dengan kriteria menarik. Indikator keempat, sebanyak 17 orang peserta atau sebanyak 70,83\% memberikan penilaian sangat menarik pada penyampaian materi yang disampaikan oleh narasumber Ibu Indri Dwi Isnaini, M.Pd. Sedangkan sisanya sebanyak 7 orang peserta atau sebanyak $29,17 \%$ berpendapat bahwa materi yang disampaikan oleh Ibu Indri Dwi Isnaini, M.Pd. berada pada kategori menarik.

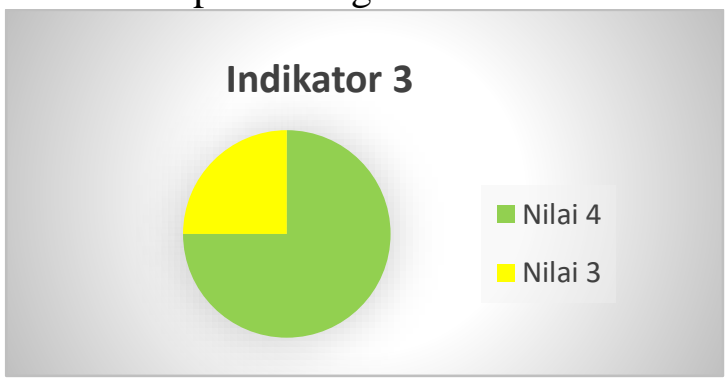

Gambar 8. Analisis Angket Respon Peserta pada Indikator 3

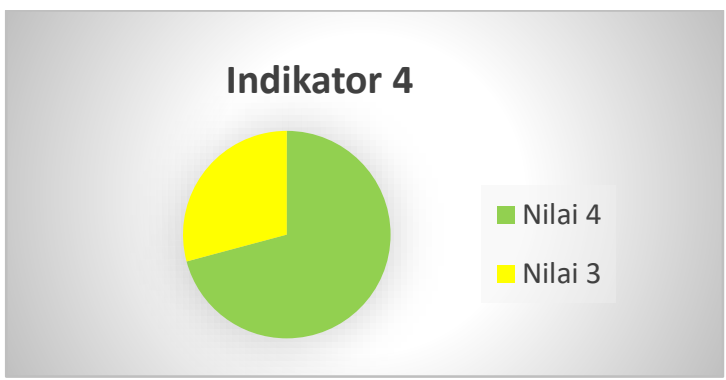

Gambar 9. Analisis Angket Respon Peserta pada Indikator 4

Indikator kelima menyatakan tentang seberapa membantu ilustrasi yang diberikan oleh narasumber untuk membantu peserta dalam memahami materi yaitu sebesar 15 orang peserta atau sebanyak $62,5 \%$ peserta setuju untuk memberikan penilaian pada kategori sangat menarik. Sedangkan sisanya, sebanyak 9 orang peserta atau 37,5\% memberikan penilaian pada kategori menarik. Pada indikator keenam, sebanyak 14 orang peserta atau sebanyak 58,33\% memberikan penilaian sangat baik terkait narasumber dalam menjawab pertanyaan dan sebanyak 10 orang peserta atau $41,67 \%$ berpendapat bahwa jawaban yang disampaikan oleh narasumber sudah cukup baik. Sedangkan pada indikator ketujuh, berkaitan dengan kebermanfaat acara parenting yang diselenggarakan ini, sebanyak 21 orang peserta atau sebanyak 87,5\% menyatakan bahwa acara parenting tersebut sangat bermanfaat. Hanya 3 orang saja atau sekitar $12,5 \%$ yang memberikan pendapat bahwa acara tersebut cukup bermanfaat.

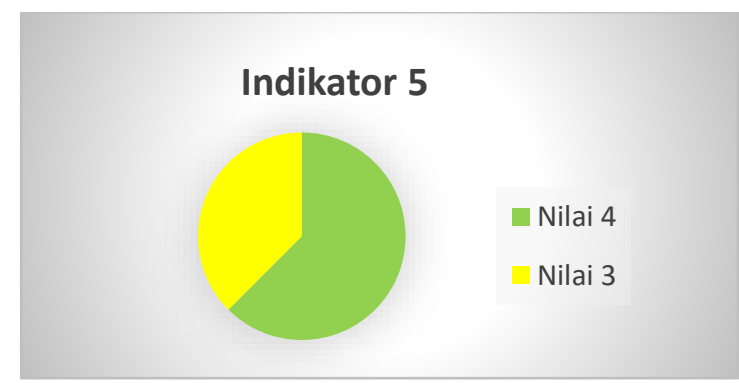

Gambar 10. Analisis Angket Respon Peserta pada Indikator 5 


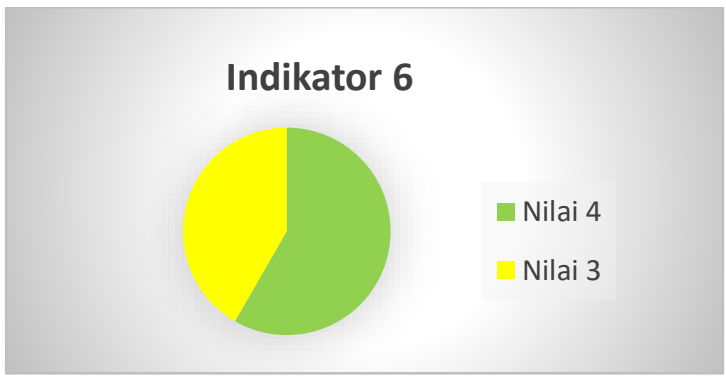

Gambar 11. Analisis Angket Respon Peserta pada Indikator 6

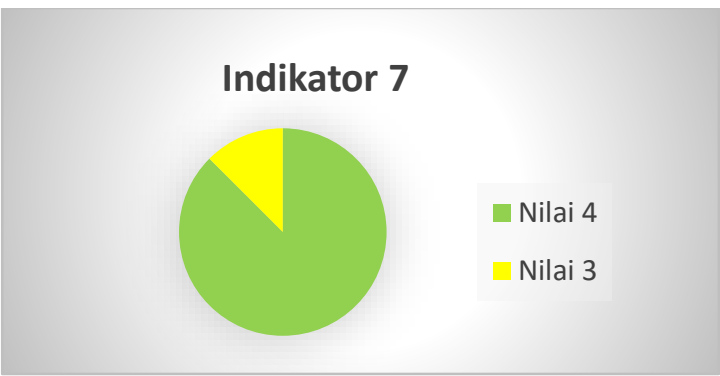

Gambar 12. Analisis Angket Respon Peserta pada Indikator 7

Pada indikator kedelapan, sebanyak 17 orang peserta atau sebanyak 70,83\% peserta memberikan penilaian sangat baik pada fasilitas yang disediakan pada kegiatan parenting yang diselenggarakan. Sisanya sebanyak 7 orang peserta atau sebesar $29,17 \%$ memberikan penilaian pada kategori baik. Sedangkan indikator terakhir yaitu indikator kesembilan, sebanyak 22 orang peserta atau sebanyak 91,67\% setuju bahwa keseluruhan acara parenting yang sudah diselenggarakan berlangsung sangat baik dan hanya 2 orang yang berpendapat cukup baik.

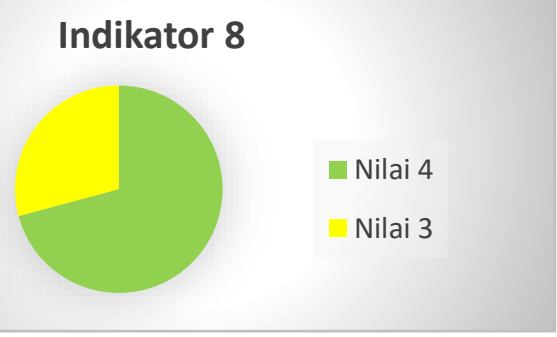

Gambar 13. Analisis Angket Respon Peserta pada Indikator 8

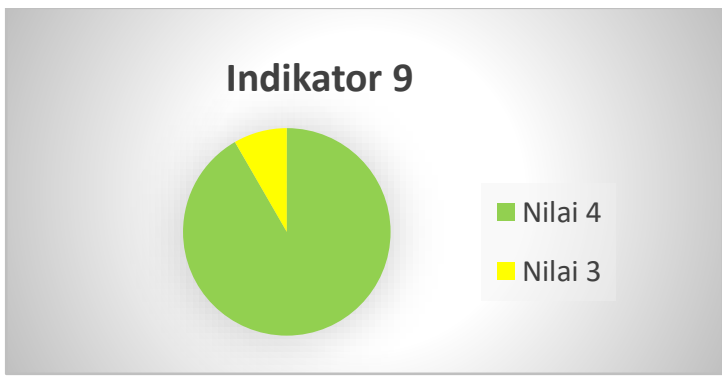

Gambar 14. Analisis Angket Respon Peserta pada Indikator 9

Selain itu, berdasarkan hasil analisis dari angket respon yang disebar luaskan kepada seluruh peserta kegiatan, sebagian besar peserta berpendapat bahwa mereka 
sangat tertarik terhadap acara parenting yang akan diadakan selanjutnya di lain hari dikarenakan kegiatan tersebut menjadikan mereka sebagai orang tua menjadi lebih termotivasi untuk menjadi orang tua yang lebih baik lagi dan tentunya menjadi lebih dekat dengan anak. Data hasil analisis angket respon peserta pun menunjukkan bahwa mereka menginginkan topik yang serupa dalam kegiatan parenting selanjutnya seperti trik cepat berhitung, cara yang menyenangkan agar anak bisa belajar.

Berdasarkan paparan di atas, menunjukkan bahwa kegiatan sosialisasi yang dilakukan dengan sasaran wali murid TK Dharmawanita Ngembeh menunjukkan hasil yang positif dengan terlihatnya antusias dari wali murid saat mengajukan pertanyaan selama berlangsungnya acara dan antusiasme untuk mengikuti kegiatan-kegiatan parenting yang akan dilaksanakan selanjutnya.

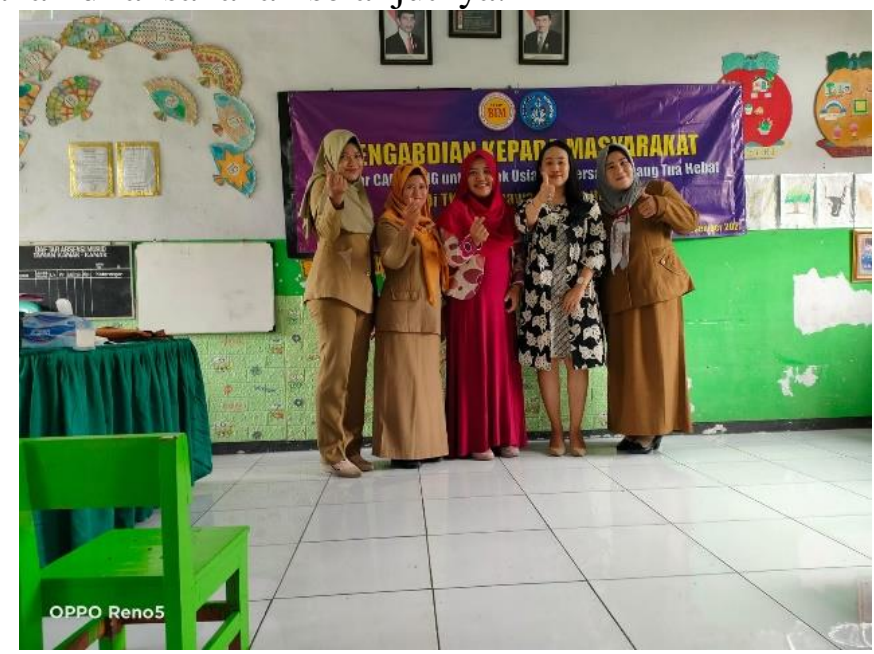

Gambar 15. Foto Bersama Narasumber, Kepala Sekolah dan Guru

\section{KESIMPULAN}

Pelaksanaan kegiatan parenting yaitu sosialisasi tentang bagaimana mengajarkan calistung untuk anak usia dini bersama orang tua hebat berjalan sangat lancar. Kegiatan berlangsung cukup menarik karena adanya diskusi antara wali murid dengan narasumber tentang kendala yang mereka hadapi saat mengajarkan anak di rumah selama masa pandemi. Respon wali murid pun cukup bagus dilihat dari antusias mereka mengajukan pertanyaan dan juga keinginan mereka untuk diadakan diskusi lebih lanjut tentang materi calistung ini.

Sedangkan saran dari pengabdian ini adalah terlaksananya kegiatan parenting secara continue kepada wali murid TK Dharmawanita Ngembeh, agar pengetahuan wali murid dalam mendidik anak ataupun mengajarkan mereka dalam belajar calistung dapat lebih baik lagi dan juga banyak ilmu-ilmu baru yang bisa mereka praktekkan saat mendidik anak di rumah. Sehingga diharapkan, anak tidak lagi membenci matematika ataupun pelajaran lainnya, kemampuan Bahasa anak dari segi komunikasi juga lebih baik. Selain itu, diharapkan sekolah juga dapat menyediakan fasilitas seperti permainan-permainan edukatif seperti balok-balok materi, puzzle matematika agar pembelajaran dapat berlangsung lebih menyenangkan.

\section{DAFTAR PUSTAKA}

Dewi, N. F. K., \& Hasanah, U. (2021). Persepsi Orang Tua Dalam Pembelajaran 
Calistung Anak Kelompok B Usia 5-6 Tahun Di TK Negeri Pembina Akhlaqul Karimah. Ceria: Jurnal Program Studi Pendidikan Anak Usia Dini, 13(2), 1624. https://doi.org/10.31000/ceria.v13i2.4012

Departemen Pendidikan Nasional. (2011) Undang-Undang Sistem Pendidikan Nasional No. 20 Th. 2003. Jakarta: Sinar Grafika.

Julianingsih, D. (2018). MATAPPA: Jurnal Pengabdian Kepada Masyarakat Bimbingan Intensif Dalam Persiapan USBN Untuk Siswa Kelas VI SD Hidayatur Rohman. 1, 1-9.

Khadijah. (2016). Pengembangan Kognitif Anak Usia Dini. Perdana Publishing.

Lisnawati, L. (2020). Pengaruh Parenting Terhadap Pemahaman Orang Tua Mengenai Calistung Anak Usia 4-5 Tahun. Jurnal Pelita PAUD, 5(1), 26-31. https://jurnal.upmk.ac.id

Marlisa, L. (2016). Tuntutan Calistung Pada Anak Usia Dini. Golden Age: Jurnal Ilmiah Tumbuh Kembang Anak Usia Dini, 1(3), 25-38. https://doi.org/10.14421/jga.2016.13-03

Napitu, H. T., \& Nasriah, N. (2019). Analisis Pelaksanaan Pembelajaran Berhitung Di TK ASSISI Medan. Jurnal Tematik, 9(2), 98-108. https://jurnal.unimed.ac.id/2012/index.php/tematik/article/view/14431

Nasir, A. (2018). Polemik Calistung Untuk Anak Usia Dini (Telaah Konsep Development Approriate Practice). ThufuLA: Jurnal Inovasi Pendidikan Guru Raudhatul Athfal, 6(2), 325. https://doi.org/10.21043/thufula.v6i2.4759

Pertiwi, D., Syafrudin, U., \& Drupadi, R. (2021). Persepsi Orangtua terhadap Pentingnya CALISTUNG untuk Anak Usia 5-6 Tahun. PAUD Lectura: Jurnal Pendidikan Anak Usia Dini, 4(02), 62-69. https://doi.org/10.31849/paudlectura.v4i02.5875

Pratiwi, E. (2015). Pembelajaran Calistung Bagi Anak Usia Dini Antara Manfaat Akademik dan Resiko Menghambat Kecerdasan Mental Anak. Prosiding Seminar Nasional Pendidikan: Inovasi Pembelajaran Untuk Pendidikan Berkemajuan, 278-283.

Sufa, F. F., \& Setiawan, M. H. Y. (2020). Memberikan Pemahaman Tentang Membaca Menulis Berhitung (Calistung) Kepada Orang Tua untuk Anak Usia Dini Feri Faila Sufa, M Hery Yuli Setiawan Universitas Slamet Riyadi. ADI WIDYA: Jurnal Pengabdian Masyarakat, 4(2). https://doi.org/10.33061

Utoyo, S., \& Arifin, I. N. (2017). Permainan Matematika (Vol. 1). Ideas Publishing.

Wahyuningsih, S., Suswantoro, E., \& Subagia, A. (2016). Bahan Ajar Untuk Guru Cerdas Bermain Matematika Bagi Anak Usia 5-6 Tahun. In Kemendikbud: PPPAUD dan Dikmas Jawa Barat. 